\title{
The Relationship between Culture and Food Abstinence Behaviour among Postpartum Mothers in the Working Area of Padang Tiji Health Center, Padang Tiji District
}

\author{
Fauziah $^{1}$, Nursinah ${ }^{2}$, Muzia Ulfa ${ }^{3}$ \\ ${ }^{1,2,3}$ Akademi Kebidanan Darul Husada Sigli, Aceh, Indonesia \\ *Corresponding Author: Fauziah, fauziah.sst@gmail.com
}

\begin{abstract}
Health development as one of the national development goals has been focused on building awareness, willingness and ability of people to live a healthy lifestyle and achieve optimal health status. Management of various governmental and community resources is needed to achieve the goasl and to provide efficient, quality and affordable health services. The purpose of this study was to determine the relationship between culture and food abstinence behavior during the postpartum period in the Padang Tiji Health Center Work Area, Padang Tiji District, Pidie Regency. Abstinence of food is not advised on postpartum mothers because it can slow down the healing process of perineal sutures. Instead, postpartum mothers are recommended to eat food in the right quality and quantity, particulary food containing protein. There were two variables in this study, namely culture and food abstinence behavior. The samples of this study were all postpartum mothers in the Padang Tiji Health Center Work area, totaling 32 people. This research was analytical with the crosssectional design. The results revealed that there is a significant relationship between culture and food taboo behavior during the puerperium. The majority of respondents $(62.5 \%)$ said that they abstained from food. The results also showed that a good culture leads to a more positive behavior (46.9\%). It is thus expected that all mothers in the Padang Tiji Health Center Work area can gain updated information on food taboos during the puerperium.
\end{abstract}

Keywords: Behavior, Culture, Dietary Restrictions, Postpartum Mothers.

\section{Introduction}

Socio-cultural values can influence all life aspects of its community members, including the dietary style of women in postpartum period. Postpartum period is a recovery period after the birth process. During this period, new mothers are scientifically recommended to have a good diet because it can accelerate the healing process of perineal wounds and improve the quality of breast milk. However, many cultures believe that food abstinence is the most effective way to improve postpartum maternal health and breast milk (Baumali, 2013).

By definition, food abstinence is the act of refraining from a particular type of food, decided personally or collectively (Marin, 2012). Most believers of food abstinence for postpartum women are shamans and the families of the postpartum women. These people are often the decision makers of what women should or should not consume since the pregnancy period. The decisions are often tradition-based, not science-based. In fact, during the postpartum period, women need food that is rich in calories, protein, fluid and vitamin (Saleha, 2012). Poor diet, such as food abstinence, can lead to malnutrition and slow down the recovery process of the birth wounds. According to Manuaba (2008), adequacy of nutrients is one of the contributing factors behind fast wound recovery.

In such cultures, postpartum women are often prohibited from eating fish because it is believed to cause puerperal blood to smell foul and not dry quickly. Eating fish is also believed to lead to itching and weakened body endurance of mothers in the postpartum 
period. In addition to fish, vegetables are also forbidden because they are associated with joint weakness (Marin, 2012).

These beliefs, as a matter of fact, are erroneous from the medical perspective. Fish, in fact, is rich in protein that can speed up the wound healing process. Vitamins in vegetables are also essential for postpartum women because they can improve the immune system and quality of milk for the newborn. Abstinence of food, hence, is not advised. Instead, postpartum mothers are suggested to eat in the right pattern, quality, and quantity (Iskandar, 2013).

To provide the best health services and improve national health development, health service providers should find out if such food taboos exist in their working area and if it is related to the local culture. Education can then be provided to reach a general understanding. In the working area of the Padang Tiji Health Center, 3 out of 10 postpartum mothers were found to believe in food taboos. Yet, the rest said that they do not practice food taboos because they need nutrition intake to breastfeed their babies. The authors were thus interested to find out if this food abstinence behaviour is related to culture. Thus, the research question that the authors would like to address is: "Is there a relationship between culture and food abstinence behavior during the postpartum period in the Padang Tiji Health Center Work Area, Padang Tiji District, Pidie Regency in 2018?".

\section{Method}

This research is analytical with a cross-sectional approach because the researchers wanted to investigate the relationship between culture and food abstinence among new mothers during the postpartum period in the Padang Tiji Public Health Center, Padang Tiji District, Pidie Regency. The population were all women with babies in the local area, totaling 32 people. The whole population was taken as research samples.

Questionnaire containing 23 questions was used as a data collection instrument. There were 3 questions about general information and 20 questions for specific research data. The latter consisted or 10 questions about behaviors and 10 questions about culture.

Data processing stages proposed by Arikunto (2010) were applied, namely:

1) Questionaire Editing.

2) Coding, in which a value of 1 was given if the answer was correct, and 0 if the answer was wrong.

3) Transferring the data into the master table.

4) Tabulating the data.

5) Doing entry, in which the research results were entered into a computer using the SPSS program application.

Univariate Analysis, or Descriptive Analysis, was carried out on each variable of the study. In general, this analysis only produces the frequency distribution and the percentage of each variable (Notoatmodjo, 2010). The analysis was carried out using the frequency distribution of each independent variable (level of knowledge and attitudes of mothers about verbal stimulation) and the dependent variable (story-reading behavior). Then, the percentage (P) was determined using the following formula (Notoatmodjo, 2010):

$$
P=\frac{F}{n} X 100 \%
$$

Description: $\quad \mathrm{P}=$ Percentage

$\mathrm{n}=$ Sample

$\mathrm{F}=$ Observed Frequency 
Bivariate analysis was also carried out. It is an analysis of the results of independent variables that are assumed to have a relationship with the dependent variable. The analysis used was cross tabulation. To test the hypothesis, statistical analysis was carried out using the Chi-square test (X2) at the significance level of 95\% (P 0.05) to show whether or not a statistically significant difference existed, using the computer program SPSS for Windows Wersion of 16.0. Through the calculation of the Chi Square test, the $\mathrm{P}$ value can be determined. If it is less than or equal to the alpha value (0.05), then Ho is rejected and $\mathrm{Ha}$ is accepted, suggesting that there is a significant relationship between the dependent variable and the independent variable (Notoatmodjo, 2010).

\section{Results and Discussions}

\subsection{Univariate Analysis}

a. Culture

Table 1. Distribution based on maternal culture in the working area of Padang Tiji Health Center

\begin{tabular}{cccc}
\hline No. & Culture & Frequency & Percentage \\
\hline 1. & Good & 17 & 53,1 \\
2. & Not Good & 15 & 46,9 \\
\multicolumn{2}{r}{ Total } & 32 & 100,0 \\
\hline \multicolumn{2}{c}{ Source: primary data (processed 2018) }
\end{tabular}

Table 1 shows that the majority of respondents (53.1\%) belong to the culture that does not advise food taboos, which is good

b. Food taboo behavior

Table 2. Distribution based on maternal behavior in the working area of Padang Tiji Health Center

\begin{tabular}{cccc}
\hline No. & Behavior & Frequency & Percentage \\
\hline 1. & Positive & 20 & 62,5 \\
2. & Negative & 12 & 37,5 \\
& Total & 32 & 100,0 \\
\hline
\end{tabular}

Source: primary data (processed 2018)

Table 2 shows that the majority of respondents practice food taboos, accounting for $62.5 \%$ (20 respondents). 


\subsection{Bivariate Analysis}

Table 3. Distribution of the relationship between culture and food abstinence in the working area of the Padang Tiji Health Center

\begin{tabular}{|c|c|c|c|c|c|c|c|c|}
\hline \multirow[t]{3}{*}{ No } & \multirow[t]{3}{*}{ Culture } & \multicolumn{4}{|c|}{ Behavior } & \multirow{2}{*}{\multicolumn{2}{|c|}{ Total }} & \multirow[t]{3}{*}{ p-value } \\
\hline & & \multicolumn{2}{|c|}{ Good } & \multicolumn{2}{|c|}{ Not Good } & & & \\
\hline & & $\mathbf{F}$ & $\%$ & $\mathbf{F}$ & $\%$ & $\mathbf{F}$ & $\%$ & \\
\hline 1 & Positive & 15 & 46.9 & 5 & 15.6 & 20 & 62.5 & \multirow{3}{*}{0,001} \\
\hline \multirow[t]{2}{*}{2} & Negative & 2 & 6.2 & 10 & 31.2 & 12 & 37.5 & \\
\hline & Total & 17 & 53.1 & 15 & 46.9 & 32 & 100 & \\
\hline
\end{tabular}

Primary data (processed 2018)

Based on Table 3, it can be seen that the "Good Culture" leads to a more positive behavior (46.9\%) than the "Not Good Culture" (15.6\%). The statistical test resulted in $P$ value $=0.005$ at alpha $5 \%(0.05)$, which means that Ho was rejected. In other words, there is a significant relationship between culture and food taboo behavior among postpartum mothers in the Padang Tiji Health Center Working Area, Padang Tiji District.

\section{Conclusions}

Based on the research findings, it can be concluded that social culture of postpartum women in the Padang Tiji Health Center Working Area, Padang Tiji District, is in the good category. Food taboo behavior during the puerperium is also in the positive category. In addition, there is a significant relationship found between culture and abstinence from food during the puerperium among the postpartum mothers in this area.

\section{References}

Arikunto, S. (2010). Prosedur Penelitian Suatu Pendekatan Praktik. Jakarta: Rineka Cipta.

Baumali, M.A.Q. (2013). Introduction to Methodology for Health Sciences. Surakarta: IPP UNS and UNS Pres.

Iskandar, I. (2013). Wrong Myths about Food. Retrieved from http://www.health.kompas.com, on 9 October 2018.

Manuaba, I. B. (2008). Gawat Darurat Obstetri Ginekologi Sosial untuk Profil Bidan. Jakarta: EGC.

Marin, M. (2012). The Relationship Between Abstinence and Food in Postpartum Mothers with the Perineal Suture Wound Healing Process. Scientific papers.

Notoatmodjo, S. (2010). Health Research Methodology. Jakarta: Rineka Cipta.

Saleha, S. (2012). Midwifery Care during Postpartum. Jakarta: Salemba Medika. 